This is the pre-review version of an article manuscript eventually published in

Constellations (at the moment only in online-first)].

The intellectual property arrangement of the publisher Wiley

makes it impossible for me to put the article as published online for public access. The article has changed considerably as compared to this version and contains many improvements suggested by the reviewers. If you quote, please refer to the published article.

Subscribers of Constellations can access the article under: http://dx.doi.org/10.1111/1467-8675.12057

If you have any questions, please e-mail me at stahl@em.uni-frankfurt.de or mail@titus-stahl.de

\title{
Habermas and the Project of Immanent Critique
}

Titus Stahl

According to his own understanding, Jürgen Habermas' Theory of Communicative Action offers a new account of the normative foundations of critical theory. ${ }^{1}$ Habermas' motivating insight is that neither a transcendental or metaphysical solution to the problem of normativity, nor a merely hermeneutic reconstruction of historically given norms, is sufficient to clarify the normative foundations of critical theory. In response to this insight, Habermas develops a novel account of normativity which locates the normative demands upon which critical theory draws within the socially instituted practice of communicative understanding.

Although Habermas has claimed otherwise, this new foundation for critical theory constitutes a novel and innovative form of "immanent critique". To argue for and to clarify this claim, I offer, in section 1, a formal account of immanent critique and distinguish between two different ways of carrying out such a critique. In section 2, I examine Habermas' rejection of the first, hermeneutic option. Against this background, I then show, in section 3, that the Theory of Communicative Action attempts to formulate an immanent critique of contemporary societies according to a second, "practice-based" model. However, because Habermas, as I will argue in section 4, commits himself to an implausibly narrow view in regard to one central element of such a model - in regard to the social ontology of immanent normativity - his normative critique cannot develop its full potential (section 5).

\section{The Concept of Immanent Critique}

Whether a particular theoretical project should be described as "immanent critique" depends on the meaning of this term which, in spite of its importance, has rarely been clearly defined. 
Hence, before turning to Habermas' model, I will clarify what I mean by "immanent critique," and the theoretical commitments I take such a project to entail.

Critical theories - or at least, those varieties which locate themselves within the Frankfurt School tradition - generally derive some of their methodological commitments from Marx's early writings. Criticizing the Utopian tendencies of his time, Marx rejects all "dogmatic" forms of normative criticism, which postulate normative principles from a context-free, external vantage point. ${ }^{2}$ However, criticizing Hegel, Marx also argues that social critique is not to be based on a reconstruction of "reason in history", but rather on an analysis of the material conditions of social reproduction. ${ }^{3}$ Thus, insofar as we can attribute any normative project to Marx, he must envisage a form of criticism that draws on norms which already exist in objective social reality. ${ }^{4}$ Many critical theorists have subsequently endorsed this broad strategy of justifying the normative standards of critique by reference to immanent potentials of social reality. In so doing, these theorists not only reject forms of moral constructivism and of moral realism that introduce norms from the "outside", but they also reject a merely "internal" application of those normative standards which are already accepted by their audience. ${ }^{5}$

However, any theory which attempts to draw on normative standards within objective social reality in this manner must solve three distinct problems: First, in order to justify a critical judgment by reference to immanent social standards, a theory must plausibly explain the sense in which such immanent standards "exist." Providing such an explanation requires a social ontology: a theoretical account that specifies the meaning of claims regarding the existence of particular social entities, and in this case, of socially immanent norms. Second, even given a justification for the assumption of immanent norms on the level of a social ontology, it is unclear what type of epistemic access social critics have to the relevant normative potentials immanent to social reality. Third and finally, it is an open question as to what kind of critical authority an immanent critique that draws upon them can aspire to. In summary, any model of immanent critique must clarify: the ontology of the immanent normative standards employed; its epistemology; and the consequences of its reliance upon those standards for its own critical capacity.

Although these questions are seldom clearly distinguished, there have been numerous attempts to address the issues they raise. We can roughly divide these answers into two camps, which I will 
term the "hermeneutic" and "practice-based" forms of immanent critique. The hermeneutic camp designates those political theorists whose social criticism attempts to draw on the interpretive resources available to members of particular social communities. From the perspective of a participant in the normative practices of such communities, such theorists argue, the relevant critical norms can be justified by specific reinterpretations of already accepted social standards. Such critique is not merely internal because the process of interpretation is thought to make available new meanings and normative commitments which have been implicit all along, but which have so far not been explicitly acknowledged. Neither is such a critique dogmatic, because it grants members of the relevant community a certain authority over the issue of which interpretation captures the meaning of their norms most authentically. Accounts of this model of social criticism are found in the writings of Michael Walzer, Charles Taylor and Alasdair MacIntyre. ${ }^{6}$

This hermeneutic strategy is, however, not the only possible understanding of an immanent method of criticism. It can hardly be assumed, for example, that Marx would have been content with his theory being described as merely a new interpretation of the ideals of bourgeois liberty, pointing out some hitherto unacknowledged aspects of their meaning. Rather, Marx's theory is an example for the second, "practice-based" type of immanent critique. On this second view, the social critic must not only draw on the cultural meanings or the rules accepted in a given community, but also on his or her knowledge about its objective practices and institutions. Practice-based immanent criticism thus presupposes that the structures and modes of interaction in a social community contain - beyond the explicit understanding of their participants immanent normative potentialities upon which a critic can draw. Clearly, not only Marx but also contemporary critical theorists like Axel Honneth belong to this second category, and, as I will argue, so does Jürgen Habermas. ${ }^{7}$

Although the hermeneutic and practice-based strategies represent two ends of a spectrum on which many intermediary positions can be found, distinguishing these strategies clarifies different potential responses to the three problems distinguished above. A hermeneutic-type strategy will answer the ontological question by postulating implicit potentials of meaning within the accepted norms and beliefs. It will describe its epistemology as one of hermeneutic interpretation, and it will answer the question of justification by pointing out the necessary commitment of participants to the consequences of an authentic interpretation of their beliefs. By contrast, a 
practice-based strategy will need to elaborate some kind of social ontology of norms within social practices. It will then have to propose at least a partly social scientific account of the epistemic access we can have to such norms, and it will answer the question of justification by describing how persons can justify demands for social change on the basis of their participation in social practices. The vagueness of this description already shows that, in contrast to the hermeneutic models, practice-based forms of social critique must differ considerably in their respective interpretation of their ontological, epistemic and justificatory commitments. Thus, any specific model of practice-based critical theory must be judged on the merits of its particular responses to these problems.

\section{Habermas and the Project of Immanent Critique}

Before Habermas' theory can be examined as an example of immanent critique, it must first be shown that this is not a misnomer, especially in the light of Habermas' explicit rejection of this description.

From its very beginning, Habermas' development of a theory of communicative rationality was a response to the exhaustion of the theoretical force of several classic models of justifying social critique. Already in the eyes of the first generation of the Frankfurt School, the Marxist model, which is based on the interests and experiences of the working class, appears outdated, both empirically and theoretically. However, only two decades after World War II, the competing model of Adorno and Horkheimer is also unable to provide answers to new theoretical and political developments. ${ }^{8}$

In his early attempts to reconsider the prospects of a philosophically guided critique of society, Habermas begins to address this seeming impasse by developing an account of an emancipatory social science that is both normatively useful and more than just a reconstruction of some particular normative standpoint. Such an ambitious form of critical theory not only requires a methodology that avoids scientific positivism - for which all talk of normative potentials within social reality is inadmissible from the start - but must also, as Habermas clearly recognizes, avoid a narrowly hermeneutic conception of social science. ${ }^{9}$

Habermas' systematic objections against hermeneutics as a general foundation for a philosophy of social science are well known. ${ }^{10}$ However, one can only fully understand why he holds that an 
emancipatory social science cannot be built on a hermeneutic model if one also considers another, more empirical assumption of his, which remains largely implicit in his methodological writings; namely, the belief that a hermeneutic form of immanent critique is historically inadequate to the reality of contemporary societies. In particular, Habermas assumes that even if there was a satisfying model of hermeneutic critique, the "raw materials" of such a critique which earlier generations could still rely on - namely, constellations of accepted social norms which allow for a progressive interpretation - no longer exist:

In the meantime, bourgeois consciousness has become cynical; as the social sciences - especially legal positivism, neoclassical economics, and recent political theory show, it has been thoroughly emptied of binding normative contents. However, if (as becomes even more apparent in times of recession) the bourgeois ideals have gone into retirement, there are no norms and values to which an immanent critique might appeal with the expectation of agreement. ${ }^{11}$

This argument, however, only applies to those forms of immanent critique that appeal to norms contained in the "consciousness" and "ideals" of a given society, that is, to forms of hermeneutic immanent critique as described above. Nevertheless, Habermas takes it to ultimately delegitimize the project of immanent critique altogether. If we recognize this one-sided understanding of “immanent critique” it follows that, despite Habermas' explicit claims otherwise, there might still be a model of practice-based immanent critique contained in his later work.

Since Habermas also rejects those practice-theoretical approaches that follow the young Marx in locating normative potentials within the practice of productive labor, ${ }^{12}$ his argument above does not reveal a return to Marxism, but rather the need for a new foundation of critical theory. While, as Axel Honneth has shown, ${ }^{13}$ Habermas temporarily entertains the idea of a reciprocal correction between objectivist and hermeneutic forms of social science, he ultimately chooses another strategy to examine the normative foundations of critical theory, by drawing instead on the practice of communication.

Habermas' first genuine attempt to formulate this new type of practice-based critique of society is his inaugural lecture on "Knowledge and Human Interests". ${ }^{14}$ His gradual elaboration of this new approach over the next decade culminates in the Theory of Communicative Action. Only in this text does he fully spell out the core commitment of his new model of critique, namely, that practices of communication contain the normative potentials of social rationality that both Marxism and the first generation of the Frankfurt School were unable to fully acknowledge. 
While he does not describe this project as "immanent critique," he does describe it as "the beginning of a social theory concerned to validate its own critical standards," 15 which draws on a "potential for critique built into communicative action itself". ${ }^{16}$ It is hard to imagine a better way of saying that one is engaged in formulating a model of immanent critique. ${ }^{17}$ Therefore, it is not surprising that his project has been understood by many of his interpreters as doing exactly this. ${ }^{18}$

\section{Normative Epistemology, Social Ontology and Critique in the Theory of Communicative Action}

If we understand the project of the Theory of Communicative Action as the development of a model of immanent critique then it clearly belongs into the camp of practice-based critique: "Communicative action" is Habermas' term for a type of social coordination made possible by the binding force of validity claims which contains - at least in modern societies - normative presuppositions with a context-transcending force ${ }^{19}$ on which a critique of society can draw. ${ }^{20}$

In developing this conception, Habermas not only subscribes to the claim that there are some normative potentials within communicative forms of social interaction, but also to the stronger claim that the relevant social practices are (at least partially) an embodiment of rationality. This stronger claim is justified by the following argument: We can understand the general concept of rationality only by reference to the concept of a valid reason which, in turn, has its primary place within practices of communication and argumentation, which is to say, in practices of exchange of speech acts. While speech acts can be used strategically, even their strategic use depends on "illocutionary force" which stems from a non-strategic "original mode of language use". ${ }^{21}$ This "original" mode is characterized by an orientation towards mutual understanding and agreement in regard to the validity claims raised. However, in order to be able to understand their speech acts as raising such validity claims, the participants must ascribe to each other not only this orientation towards mutual understanding, but also - at least in the more demanding forms of postconventional discourse - the acceptance of certain norms of discourse which prohibit the arbitrary exclusion of arguments or speakers, and which obligate speakers to formulate their practical demands in view of the generalizable interests of everybody. ${ }^{22}$ Hence, the practice of communicative action contains within itself a potential for rationality that Habermas terms "communicative rationality." 23 Habermas' conception of communicative rationality serves at once to supplement the one-sided focus of Weberian rationalization theories on increases in 
instrumental rationality ${ }^{24}$ and to designate the immanent potential in social practices on which a critical theory of society is to rely. ${ }^{25}$

With this account of Habermas' theory in place, it is possible to distinguish his response to the three questions of normative epistemology (I), social ontology (II) and critique (III) raised above.

(I) Normative Epistemology: Habermas calls his method of reconstructing the normative presuppositions of understanding in the Theory of Communicative Action "formal" or "universal pragmatics": ${ }^{26}$ Formal pragmatics is a type of reconstructive theory that unearths the idealized presuppositions of communicative language use. Because of its idealizations, this method is not a purely empirical reconstruction of language use. Nor is it a purely transcendental method however, because it is still subject to empirical tests. In any case, it turns out that the preconditions Habermas ascribes to communicative action - and thus its potentials - are not fully understandable drawing only upon formal theories of language. ${ }^{27}$ Rather, the very possibility of reflexive consideration of validity claims presupposes shared contexts of meaning, background knowledge and established normative practices, which is to say, a shared and symbolically structured "lifeworld" 28 that cannot be fully characterized from a merely formal perspective. Therefore, formal pragmatics are, on Habermas' account, not a foundationalist method of deriving norms, but must be complemented by a social theory of the lifeworld.

(II) Social Ontology: While Habermas is not explicitly concerned with social ontology - as spelled out, for example, by accounts like those of John Searle, Margaret Gilbert or Raimo Tuomela ${ }^{29}$ - many of his theoretical commitments are relevant in this context: ${ }^{30}$ The core claim of Habermas' account of communicative action is that practices of communication have a rational potential built in. ${ }^{31}$ If we take ourselves to be engaged in such a communicative practice, then we are, qua participation, committed to certain rules and standards. Prima facie, this looks like a classic constructivist account: If communication is an essential, non-optional practice, and if - from the perspective of a participant in this practice - we cannot deny that we are bound to certain norms without performative contradiction, then these norms have binding force. If we interpreted Habermas in this constructivist sense, his account would no longer be one of immanent critique, because the force and the validity of the relevant norms would be guaranteed as a matter of the pragmatic structure of communication. As Habermas' engagement with social theory shows however, he rejects this constructivist option, since the normative potentials he 
finds in communicative action are neither historically invariant nor transcendentally given. Rather, the transition from pre-modern to modern societies not only involves a differentiation of validity claims but also a change in the foundation of normative validity. Specifically, in pre-modern societies the normative force of validity claims rests on the presupposed symbolic consensus established by tradition and religious authority. By contrast, the background conditions which make communicative agreement possible in modern societies can only be understood within a communicatively structured social lifeworld, which is a constellation of the three structural components of cultural background knowledge, legitimate social norms and personal identities. This social lifeworld is not traditionally enforced, but rather reproduces itself through communicative processes that do not presuppose the validity of traditional norms. ${ }^{32}$ In this way, the lifeworld is - in modern societies - both a structural precondition of communicative action and the result of social integration through communication. ${ }^{33}$

Habermas' concept of the lifeworld introduces a component which cannot be described without empirical and historical vocabularies, and so suggests a picture of normativity that is at least partially one of social immanence. ${ }^{34}$ Even though Habermas does not spell out an explicit social ontological account of how exactly the relevant norms are instituted, his strong emphasis on the lifeworld hints at the following understanding. On the one hand, the practice of communicative action, formally characterized, firstly explains the normative force of communication, because the very activity of raising validity claims requires binding oneself to certain normative standards. Secondly, the practice of communicative action attributes a minimal, formally defined normative content to communication in the form of the idealized presuppositions of communication. ${ }^{35} \mathrm{On}$ the other hand, the lifeworld designates a set of constitutive preconditions for the possibility of communicative action, which provide for motivational resources and enable communicative demands to result in specific commitments. Hence, in Habermas' work the concept of the lifeworld marks the point at which critical norms are immanently grounded in social reality; although of course, Habermas does not envisage just any kind of norm being grounded in the lifeworld, but rather the context-transcending, universal norms that the non-optional implications of communicative action support.

(III) Critique: Finally, a model of immanent critique must show that the immanent norms of communication are actually suited for social criticism. This part of the Theory of Communicative Action is, for reasons that are easy enough to understand, the most contested. ${ }^{36}$ Habermas does 
not provide a systematic justification for a critique of society that directly draws upon the normative potentials that are institutionalized within communicative practices. He does not, for example, focus on a critique of practices in which arguments or speakers are systematically excluded.$^{37}$ Rather, with his theory of colonization, he provides a higher-order account of social pathologies. The "colonization thesis" rests upon an analytical distinction between communicative and strategic modes of action coordination, or in other words, between social reproduction from the lifeworld and system perspectives. The lifeworld constitutes a perspective on the symbolic reproduction of background knowledge, personality structures and normative agreement, while the "system" designates structures of functional coordination of action and material social reproduction that do not depend on communicatively generated understanding. While Habermas still describes the "uncoupling" of system and lifeworld, which results from the historical process of differentiation between fully communicative and functional forms of action coordination, ${ }^{38}$ in neutral terms, his theory becomes critical as soon as he analyzes the colonization of the lifeworld; that is, the suppression or undermining of communicative coordination by the invasion of systemic mechanisms into practices which constitutively depend on communication. ${ }^{39}$ Processes of colonization - in which systemic rationality oversteps its proper bounds - not only cause a loss of legitimacy, a fragmentation of everyday consciousness, a loss of freedom and meaning ${ }^{40}$ and cultural impoverishment, ${ }^{41}$ they also endanger the integrative function of the lifeworld by attacking the very "infrastructure" upon which the processes themselves rely. ${ }^{42}$ The suppression of communicative rationality through colonization by system imperatives is supposed to explain not only pathologies - i.e. tendencies of a self-undermining rationalization process - but also the normative source of social protests against rationalization. ${ }^{43}$ While Critical Theory is not directly guiding such protests, it can at least articulate the contrast between communicative ideals and the processes against which these social protests are directed. On this last issue however, Habermas theory is surprisingly cautious: ${ }^{44}$ Even though he announces the Theory of Communicative Action as an analysis of the normative basis of critical theory, he does not actually spell out directly which norms can justify a critique of society, ${ }^{45}$ but rather describes only the learning potentials and functional accomplishments of a mode of practice that is blocked by the processes of one-sided rationalization. Despite this reservation, Habermas' combination of the method of pragmatics, his social theory of communicative rationalization and the thesis of the self-undermining character of rationalization nonetheless 
reflects the intention of the Theory of Communicative Action to develop the elements of a practice-based immanent critique.

\section{Ambiguities in Habermas' Implicit Social Ontology}

Having sketched the shape of Habermas' project, it might not seem that his social ontology of immanent normativity needs further elaboration. However, if one examines his account of the lifeworld more precisely, there are several ambiguities which suggest that a more substantial social ontological account is required. In this section, I attempt to show that Habermas' distinction between a formal pragmatic and a sociological conception of the lifeworld leads him to wrongly assume that there is no problem of social ontology to be solved (I). For the same reason, Habermas does not distinguish questions about the normative function of lifeworld norms from questions about their constitution (II). This leads to an implausible form of the distinction between lifeworld and system (III), and in turn, as I will show in section 5, to several problems in his model of social critique.

(I) The formal pragmatic and the sociological conception of the lifeworld: Habermas understands both the normative force of specific validity claims, and the normative force of the more general idealizations presupposed in genuine attempts to reach understanding as supported by context-transcending structural norms of communication, and as dependent on the normative resources of the lifeworld. This dependence of the normative force of the form of communication on the concrete resources of a historically given lifeworld seems to undermine the claim of an autonomous normative potential of communicative action. ${ }^{46}$ It also prompts a question as to whether Habermas' conception of a purely communicative lifeworld - in which this normative potential is supposed to be concentrated - does not amount to a misleading exclusion of the phenomena of power and domination which can be empirically found in existing structures of symbolic integration. ${ }^{47}$

In response to this criticism, Habermas has emphasized the distinction between a formal pragmatic and a sociological conception of the lifeworld: ${ }^{48}$ The formal pragmatic conception of the lifeworld explains how, from the first-person perspective of participants, a background of lifeworld resources may always be presupposed as unproblematic from within contexts of communicative action. ${ }^{49}$ By contrast to this internal perspective, the sociological conception describes the reproduction of the necessary resources from the third-person perspective of the 
sociologist who can acknowledge the force of non-communicative processes in the empirically existing lifeworld. Having made this distinction, Habermas assumes that one can understand the binding force of communicative normativity (which is only accessible from the perspective of a potential interlocutor, that is, from the formal pragmatic perspective) as conceptually independent from the sociological perspective on social norms. This means that, by presenting a theory of social evolution that explains the evolution of lifeworlds from a traditional to a communicative logic, he sees himself as capable of fully explaining the force of communicative norms from within this communicative logic using the resources of his formal pragmatics of communication, without needing an additional account of their social ontology.

However, the distinction between the formal pragmatic and the sociological conception of the lifeworld on which this argument rests is ultimately problematic even within Habermas' own theory, because it creates the following dilemma: On the one hand, Habermas cannot rely on the perspective of participants in communicative action alone to explain the contribution of the lifeworld to communicative agreement, since from this perspective, lifeworld norms cannot become thematic at all. Consequently, Habermas can not use the communication theoretic conception of the lifeworld to explain the contribution of the lifeworld resources to communicative understanding. For this purpose, he rather introduces the "everyday concept of the lifeworld," ${ }^{50}$ which denotes the lifeworld from the perspective not of participants, but of "narrators". ${ }^{51}$ It is unclear, however, how far this third standpoint really constitutes a self-standing perspective. ${ }^{52}$ If, as Habermas suggests, the narrative perspective - in which the lifeworld can, in contrast to the participant perspective, become thematic - indeed enables "statements about the reproduction or self-maintenance" ${ }^{23}$ of the lifeworld, it is not obvious how exactly this perspective can be conceptually distinguished from the sociological one; nor is it clear that such statements must necessarily presuppose an unproblematic character of the lifeworld norms. If we were indeed able to adopt a self-standing formal pragmatic perspective in which the normative foundations of the lifeworld nevertheless could become thematic, the question would necessarily arise whether such a perspective also allows us to criticize these norms as, for example, effects of power. An answer to this question that remained committed to the unproblematic character of these norms would raise numerous objections as to whether a theory of communicative action could use this idealizing perspective to reconstruct binding normative presuppositions, or whether it would not rather deserve the same criticism which Habermas had 
originally reserved for the hermeneutic theories.

On the other hand, if Habermas allowed for sociological insights into the empirically given social practices and institutions of the lifeworld to genuinely contribute to the understanding of the normative force of communicative action, it would no longer be obvious that we can indeed understand the force of all aspects of communicative normativity from the perspective of its internal logic. ${ }^{54}$ Most importantly, the issue would remain unsolved whether we are allowed to neglect the question whether the institutional foundations of communicative normativity also include non-communicative social relations. ${ }^{55}$ This question, which will be discussed more extensively in the following section, cannot be answered without a more substantial account of the social ontology of the lifeworld.

(II) The conflation between normative function and social ontology: Since Habermas considers the combination of a theory of social evolution and formal pragmatics to be sufficient to understand the normative constitution of the lifeworld, he commits himself to an implicit social ontology that amounts to a radical form of social ontological monism. More specifically, since Habermas assumes that, from within the formal pragmatic perspective, we must understand all traditional forms of symbolic consensus to have been replaced by communicative agreement ${ }^{56}$ in modernity, and because he endorses the thesis that communicative action is - again, from within this perspective - sufficient to understand the reproduction of modern lifeworlds, ${ }^{57}$ he is committed to the thesis that we can answer all constitutive questions within the social ontology of immanent norms with a theory of communication. Moreover, because he identifies the normatively relevant accomplishments of the lifeworld - from its internal perspective - as consisting in its capacity for communicative rationality, and because he analyzes the binding force of the relevant norms as operating only through communicative validity claims, he restricts the analysis of the mode of institution of lifeworld norms to those processes which can be described within a model of communicative reproduction. ${ }^{58}$ Habermas thus effectively argues from the premise that we - as participants - can only understand those norms to have binding force which we can also understand as being, in principle, justifiable in discourse, and he takes this premise to imply the truth of a social ontological thesis about the mode of institution of critical norms. The validity of this implication depends, however, on the assumption that we can derive insights in social theory from a lifeworld standpoint and effectively entails a "conceptualization of society from philosophical premisses". ${ }^{59}$ But this assumption restricts the social ontology of immanent 
normativity considerably: While Habermas criticizes the hermeneutic fiction ${ }^{60}$ that social integration is only accomplished through undistorted communication, and although he even occasionally stresses that phenomena of power and strategic action are empirically relevant for the reproduction of the resources of the lifeworld, ${ }^{61}$ he ultimately considers these phenomena to be irrelevant for the specific task of understanding the lifeworld's capacity to institute the kind of social normativity that provides the foundation for his critical project. ${ }^{62}$

This narrow focus on a purely communicative model of the institution of normative demands excludes, from the outset, the question of whether there could also be normative potentials that we can understand as having binding force that are instituted by other forms of practices. That is, Habermas assumes that there are no relevant communicatively redeemable, but non-communicatively instituted normative potentials implicit, for example, in structures of non-communicative intersubjective authority relations, ${ }^{63}$ affectivity or cooperation. If such sources of normative force were acknowledged, then a critical theory would be possible that would not need to understand the entire normative force of critique as in principle explicable within a communicative standpoint. This critical theory would then be able to recognize critical potentials even within practices that do not accord a privileged role to communicative action. ${ }^{64}$ But as long as competing accounts of social ontology - that is, of the mode of institution of norms - that rely on such structures are not even considered, critical theory is condemned to get only as much potential for rationality out of the lifeworld as it has conceptually invested into it, since it restricts itself to those forms of the reproduction of normativity that are singled out for normative reasons.

(III) The problematic distinction between lifeworld and system: The exclusion of non-communicative elements of the lifeworld from Habermas' social ontology is closely connected to his contrast between lifeworld and "system". While the analytical distinction between these two modes of integration has considerable advantages for his theory of rationalization, it is dangerous insofar as it leads Habermas ultimately to accept a functionalist analysis of social integration as described from the third-person perspective. ${ }^{65}$ Even though, in Habermas' view, all forms of systemic integration presuppose the irreducible existence of a communicatively integrated lifeworld because "they have to be institutionalized", ${ }^{66}$ his narrow conception of the social ontology of lifeworld normativity leads him to rigidly separate processes of communicative integration from processes of systemic integration. Although the conditions of 
systemic integration are instituted by communicative agreement, they do not draw upon such agreement. ${ }^{67}$ Hence, they must be described as free from any relevant internal normative conflicts. ${ }^{68}$ Thus, for conceptual reasons, normatively relevant social conflicts can only be caused by the tendency of the spheres of systemic social integration to violate the norms of clearly distinguishable social practices in the communicatively structured lifeworld. ${ }^{69}$

This feature of Habermas' analysis excludes any theoretical attempt to understand the normative institutionalization of systemic coordination mechanisms in a way that allows for the question whether there are normative attitudes or expectations built into non-communicative practices which these mechanisms can frustrate or fulfill. ${ }^{70}$ However, as long as Habermas cannot ask this question, his general critique of functionalism has only limited consequences for his normative project. It remains restricted to a weak formulation which only states that, contrary to the assumptions of systems theory, the mode of coordination within systemic spheres as a whole depends on the lifeworld. This is, however, insufficient for a convincing normative critique of specific forms of systemic action coordination. An immanent critique of practices guided by systemic rationality would be possible only if Habermas extended his argument against functionalism to include the claim that systemic action coordination within specific social practices draws in its concrete modes of operation ${ }^{71}$ on immanent normative resources from the very same social practices. ${ }^{72}$

If Habermas were to strengthen his anti-functionalist thesis in this way he might conceive of systemic coordination not as a self-regulating sphere of non-normative mechanisms, but rather, as I will suggest in more detail in the next section, as a distinct type of second-order normative self-regulation of social practices. This perspective would provide him with resources for a normative critique of colonization. However, it would also require Habermas to give up the social ontological monism of communicative action, because he would need to ascribe normative potentials to non-communicatively instituted practices.

\section{Ambiguities of the Model of Critique}

Having argued that Habermas does not develop the social ontology of communicative action in a satisfying way, I now want to argue that the ambiguities of Habermas' social ontology of normativity, and especially those concerning the degree of independence of communicatively generated normative force from power and domination, have substantive normative implications 
for his mode of social critique.

We can examine the extent to which immanent norms of communication can provide a standard for social critique at three levels: ${ }^{73}$ First, a social critique might attempt to criticize specific normative arrangements by recurring to the immanent norms of discursive practices. This obviously is not what Habermas has in mind: The norms of discourse that can be reconstructed by universal pragmatics do not directly determine what people must agree on in concrete discourses. Rather, these norms only specify what will count as acceptable discourse. While Habermas has previously attempted to formulate a more substantial account of social critique using a model of universalizable interests ${ }^{74}$ and while this model remains central for his discourse ethics, ${ }^{75}$ he more or less gives up on the attempt to derive significant conclusions for a large-scale critical social theory from this line of thought. ${ }^{76}$

Habermas describes the critique on the second level as a critique of "systematically distorted communication". This expression describes instances of supposedly communicative action where agents are forced to systematically, but covertly and unconsciously, violate communicative norms due to some constraint. This concept, which Habermas developed in the $1970 \mathrm{~s},{ }^{77}$ is still present in his later work, especially as the complement to the idealizations that are reconstructed by formal pragmatics. ${ }^{78}$ However, Habermas refrains from systematically exploiting this idea for his critique of society. ${ }^{79}$ On the rare occasions on which he mentions the concept of distorted communication in this context, he oscillates between rejecting it as a model for the understanding of systemic imperatives - which, in his words, do not deceive but rather "openly come [...] from the outside" ${ }^{\prime 80}$ and claiming that it is constitutive of social pathologies in general. ${ }^{81}$

The third and final level of superseded communication is the level at which the colonization thesis must be discussed. At this level, Habermas distinguishes between legitimate forms and problematic forms of mediatization. While legitimate forms replace communicative coordination by systemic coordination in ways that enable the production of material wealth to compensate for losses of communicative coordination, problematic forms of colonization endanger the life-world. ${ }^{82}$ Habermas uses the latter expression to describe processes of mediatization which lead to fragmentation, delegitimization, cultural impoverishment and disintegration. ${ }^{83}$ Surprisingly, however, all these descriptions - with the possible exception of the decline of the integration of the different value spheres - refer to social dysfunctionalities caused by colonization, ${ }^{84}$ and 
especially to the loss of the capacity of communicative processes to continue to perform their functions of legitimation and of integration of the self and the community, rather than to violations of normative expectations that inhere in the communicative process itself. ${ }^{85}$ It has been widely objected that this functional criterion is neither able to provide a standard that allows to distinguish (normatively) legitimate from illegitimate delinguistification ("Entsprachlichung") nor a standard which would be suited to criticize colonization from the perspective of communicative rationality. ${ }^{86}$ In other words, it is argued that this form of critique is incapable of justifying particular demands for social change employing the norms immanent in communicative practices, rather than relying on the implicit premise that dysfunctionalities of symbolic integration are, as such, normatively problematic. ${ }^{87}$

Since Habermas only allows for a narrowly conceived communicative foundation for immanent normativity, he has no recourse to substantive immanent norms when he sets out to criticize the effects of non-communicative social integration. Although this weakness has widely been recognized, it can only be fully understood if one contrasts Habermas' restricted, monistic social ontology with a richer account that locates the institution of norms within contested practices of intersubjective authority ascription. If we were to allow that not only communicative, but also non-communicative elements of social practices can constitute a source of normative force of critical demands, we could paint a picture of social norms according to which colonization processes violate the immanent norms of particular social practices.

We can only develop such an account however if we shift the focus of the debate away from issues concerned with the correct understanding of the structures of discourse and argumentation, and away from elaborating normative ideals like autonomy or rationality, towards the question of what social authority critique can claim. ${ }^{88}$ Hence, to develop a plausible social ontology, we must rather focus on the different modes in which shared social norms can be instituted, and on the internal potentials these modes offer for critique. This analysis must be guided by the hope that clarifying the social authority of critique will furnish new criteria to distinguish changes to structures of social norms that are rational and inclusive from illegitimate normative transitions that rest on power structures which only pretend to have a claim to legitimate acceptance. ${ }^{89}$

Of course, such a model of a critical social ontology needs much more elaboration to be 
plausible. ${ }^{90}$ However, if we could make sense of the idea that there are unrealized normative potentials in social practices, we might be able to formulate a richer account of the normative basis of the distinction between legitimate and illegitimate delinguistification. This is because, on such an account, it is possible to distinguish between various types of practices that institute different kinds of second-order norms to regulate the entitlements of the participants in regard to their role in the administration of first-order, social norms. In some practices, the mode of practical authority ascription implies that the participants are not normatively entitled to demand justifications for certain interpretations of the rules of the practice. Other practices, in contrast, involve forms of recognition which constitute a mutual ascription of entitlements to a communicative justification of controversial normative evaluations. When practices of the first type are integrated into systems of media-based coordination, this does not necessarily produce violations of normative expectations. However, practices of the second type must be described as pathological in a normative sense whenever their participants are forced to submit to rules that effectively undermine their normative status, because this amounts to a structural violation of the entitlements that are constitutive of the practice in question. We could, for example, understand the colonization of educational institutions by money or administrative power in this sense. That is, one could claim that there are practices in educational institutions that constitutively depend on a reciprocal recognition that the participants are entitled to justification for all relevant demands made upon them. As soon as such practices are constrained by rules which prevent this recognition from becoming explicit as demands for justification, then participants are forced to treat all conflicts within the practice as merely strategic, and are thereby prevented from realizing the entitlements that are constitutive of their recognitive statuses within this practice.

To describe conflicts over colonization in this way, however, entails a fundamental revision of Habermas' theory. To speak of a conflict between suppressed practice-immanent normative expectations on the one hand, and second-order norms that prevent them from becoming explicit on the other hand, necessarily presumes that there are sources of normativity beyond those elements of the lifeworld which can - at least in principle - become explicitly thematic at any time. On such an account, the normativity of the lifeworld must originate in a structure of practical cooperation and of mutual recognition which practically institutes normative demands independently of a communicative affirmation of these norms as binding. This proposal amounts, therefore, to the claim that the normative force of communicative rationality depends, 
from a social ontological perspective, on the institution of practical demands which cannot exhaustively be described in communication terms. ${ }^{91}$

Even though this modification risks losing some of the power of Habermas' theory of rationalization, and significantly complicates the issue as to whether the standards of critique are universal, it not only allows for a normative distinction between two types of practices, it also enables the model of communicative critique to be expanded to describe forms of pathologies within systemically coordinated action spheres that Habermas is forced to remain silent about. Specifically, we can conceive of de facto systemically organized practices where the relevant non-communicative second-order norms are not instituted by the acceptance of all participants involved, but by domination or ideology. We can, for example, conceptualize practices of collaboration in industrial or service work as social practices with inbuilt normative demands that particular organizational arrangements be justified, which are not allowed to be communicatively raised within the practices themselves because the action of raising such demands is excluded from the range of actions which count as a part of these practices. A critique of this type of forced delinguistification must be based on a normative criterion which distinguishes different practices based on their internal normative organization. Only then it becomes possible to formulate a social critique of such practices that justifies why they should not remain subsumed under a functional logic, as opposed to only explaining why such a subsumption cannot occur without a loss of meaning.

\section{Conclusion}

Even though the methodological issue of immanent critique is rarely labeled as such, it remains crucial for contemporary critical theory. As an influential exponent of immanent criticism albeit implicitly - Habermas' paradigm shift in the Theory of Communicative Action has provided both new resources and new problems. In particular, his account of the social foundations of communicative action - even though normatively attractive - tends to obstruct our view of the complex preconditions of institutional reality, and thus obscures the plurality of normative arrangements that underlie these practices. Hence, a convincing reformulation of immanent critique will have to go beyond his model by explicitly addressing the social ontology of the normative potentials of social practices, for example, by drawing on recent attempts to connect the current discussions in analytic philosophy with the theory of recognition. ${ }^{22}$ Such 
developments open up new opportunities for a theory of immanent critique that is empirically and normatively convincing, and that is able to understand itself as making explicit the political conflict over the constitutive authority which our participation in social struggles presupposes. ${ }^{93}$

Titus Stahl is Assistant Professor of Philosophy at Johann Wolfgang Goethe University in Frankfurt, Germany. 
1 Cf. Jürgen Habermas, The Theory of Communicative Action, tr. Thomas McCarthy (Boston: Beacon Press, 1984), Volume 1, p. xxxix (from now on quoted as TCA).

2 cf. Karl Marx, "Letters from the Deutsch-Französische Jahrbücher", Karl Marx, Frederick Engels: Collected Works, Vol. 3: 1843-1844, tr. Jack Cohen, et. al. (International Publishers: New York, 2005), 142ff.

3 Rüdiger Bubner, "Habermas's Concept of a Critical Theory", John B. Thompson and David Held, eds., Habermas. Critical Debates (London: MacMillan, 1982), 43.

4 Sheyla Benhabib, Critique, Norm, and Utopia (New York: Columbia University Press, 1986), 328.

5 Antti Kauppinen, "Reason, Recognition, and Internal Critique", Inquiry 45(4), 479-498; Maeve Cooke, Representing the Good Society (Cambridge, MA: MIT Press, 2006), ch. 3.

6 E.g. Michael Walzer, Interpretation and Social Criticism (Cambridge, MA: Harvard University Press, 1987).

7 Kauppinen, "Reason, Recognition, and Internal Critique"; for Honneth especially his "The Social Dynamics of Disrespect: On the Location of Critical Theory Today", Disrespect. On the Normative Foundations of Critical Theory (Cambridge: Polity, 2007), 63-79.

8 Benhabib, Critique, Norm, and Utopia, 225; Jürgen Habermas, The Philosophical Discourse of Modernity (Cambridge: Polity, 1987).

9 Jürgen Habermas, On the Logic of the Social Sciences, tr. Shierry Weber Nicholsen and Jerry A. Stark (Boston: MIT Press, 1988).

10 Jürgen Habermas, "Interpretive Social Science vs. Hermeneuticism”, Norma Haan, Robert N. Bellah, Paul Rabinow and William M. Sullivan, eds., Social Science as Moral Inquiry (New York: Columbia University Press, 1983), 251-269; Axel Honneth, The Critique of Power, tr. Kenneth Baynes (Cambridge: MIT Press, 1991), 225; Nicholas H. Smith, Strong Hermeneutics. Contingency and Moral Identity (London: Routledge, 1997), $27 f$.

11 Jürgen Habermas, "Historical Materialism and the Development of Normative Structures", Communication and the Evolution of Society, tr. Thomas McCarthy, (Polity Press, Cambridge 1991), 96f.; Jürgen Habermas, "Technology and Science as 'Ideology', Toward a Rational Society, tr. Jeremy Shapiro (Boston: Beacon Press, 1970), 107ff.; TCA 2, 352f.

12 Cf. Habermas, "Technology and Science as 'Ideology"”, 91ff.; Thomas McCarthy, The Critical Theory of Jürgen Habermas, (Cambridge, MA: MIT Press, 1978), 22f.

13 Honneth, The Critique of Power, 227.

14 Jürgen Habermas, "Knowledge and Human Interests. A General Perspective", Knowledge and Human Interests, tr. Jeremy J. Shapiro (Cambridge: Polity, 1987), 301-317.

15 TCA 1, xxxix.

16 TCA $1,121$.

${ }_{17}$ Cf. his remark, written at roughly the same time, that "like Marx's, my theoretical approach is guided by the intention of recovering a potential of reason encapsulated in the very forms of social reproduction". (Jürgen Habermas, "A Reply to My Critics", John B. Thompson and David Held, eds., Habermas. Critical Debates (London: MacMillan, 1982), 221.

18 Herbert Schnädelbach, "The Transformation of Critical Theory", Axel Honneth and Hans Joas, eds., Communicative Action, tr. Jeremy Gaines and Doris L. Jones (Cambridge: Polity, 1991), 21; Maeve Cooke, "Avoiding Authoritarianism: On the Problem of Justification in Contemporary Critical Social Theory", International Journal of Philosophical Studies 13(3), 2005, 390; Cooke, Representing the Good Society, ch.3; Benhabib, Critique, Norm, and Utopia, 22.

19 TCA $1,120$.

20 Cf. Jürgen Habermas, "Toward a Reconstruction of Historical Materialism", Communication and the Evolution of Society, tr. Thomas McCarthy (Cambridge: Polity, 1991), 177.

21 TCA $1,288$.

22 Jürgen Habermas, "Themes in Postmetaphysical Thinking”, Postmetaphysical Thinking (Cambridge, MA: 1992), 46f.; Jürgen Habermas, "What is Universal Pragmatics", Maeve Cooke, ed., On the Pragmatics of Communication (Cambridge, MA: MIT Press, 1998), 21-104. Jürgen Habermas, "Discourse Ethics: Notes on a Program of Philosophical Justification", Moral Consciousness and Communicative Action, tr. Christian Lenhardt and Shierry Weber Nicholsen (Cambridge, MA: MIT Press, 1990), 86ff.

23 TCA $1,17$.

24 Benhabib, Critique, Norm, and Utopia 254.

25 TCA $1,120$.

26 Cf. John B. Thompson, "Universal Pragmatics", John B. Thompson and David Held, eds., Habermas. Critical Debates (London: MacMillan, 1982), 116-133.

27 TCA $1,330$.

28 TCA 1, 337; Jürgen Habermas, "A Reply", Axel Honneth and Hans Joas, eds., Communicative Action, tr. Jeremy Gaines and Doris L. Jones (Cambridge: Polity, 1991), 244.

29 For a suggestion how to supplement Habermas' theory with such accounts, see Wolfgang Detel, "System und Lebenswelt bei Habermas”, Stefan Müller-Doohm, ed., Das Interesse der Vernunft (Frankfurt: Suhrkamp, 2000), $194 f$.

30 Cf. James G. Finlayson, Habermas. A Very Short Introduction (Oxford: Oxford University Press, 2005$), 51$.

31 TCA 2, 47, 75, 86 . 
32 TCA 2, 107 139-145.

33 TCA 2, 145; Benhabib, Critique, Norm, and Utopia 238-239.

34 Habermas, "A Reply", 244.

35 Habermas, "Discourse Ethics: Notes on a Program of Philosophical Justification"; TCA 2, 72, 95ff.

36 Cf. Thomas McCarthy, "Complexity and Democracy, or the Seducements of Systems Theory", New German Critique 35, 1985, 27-53.

37 Habermas, "Toward a Reconstruction of Historical Materialism", 177.

38 TCA 2, 173ff.

39 TCA 2, 196.

40 TCA 2, 318, 323.

41 TCA 2, 330

42 TCA 2, 327, 375

43 TCA 2, 393ff

44 Johannes Weiss, "Verständigungsorientierung und Kritik", Kölner Zeitschrift für Soziologie und Sozialpsychologie, 35(1), 1983, 114.

45 Cf. his remark on "the normative meaning of democracy" in TCA 2, 345, but also his much stronger remarks in Habermas, "Toward a Reconstruction of Historical Materialism", 177.

46 Habermas, "A Reply", 244f.; Weiss, "Verständigungsorientierung und Kritik", 113; Cooke, "Avoiding Authoritarianism", 391.

47 Honneth, The Critique of Power, 299; William Outwaithe, Habermas. A Critical Introduction (Cambridge: Polity 1994), 113f.

48 Habermas, “A reply", 245ff.; Jürgen Habermas, "Actions, Speech Acts, Linguistically Mediated Interactions, and the Lifeworld (1988)", Maeve Cooke, ed., On the Pragmatics of Communication (Cambridge, MA: MIT Press, 1998), 239ff., this distinction is anticipated in TCA $1,123 \mathrm{f}$.

49 TCA 2, 148f.

50 TCA 2, 135, emphasis T.S.

51 TCA 2, 137.

52 Schnädelbach, "The Transformation of Critical Theory", 18; Simone Dietz, Lebenswelt und System (Würzburg: Königshausen \& Neumann, 1993), 98ff.

53 TCA 2, 137.

54 Cf. Cooke, “Avoiding Authoritarianism”, 394.

55 Johannes Weiss, “Die 'Bindungseffekte kommunikativen Handelns'. Einige skeptische Bemerkungen”, Axel Honneth and Hans Joas, eds, Kommunikatives Handeln (Frankfurt: Suhrkamp, 2002), 447; Honneth, The Critique of Power, 299.

56 TCA 2, 93, 107

57 "If we consider society in the broader sense as a symbolically structured lifeworld, it is certainly true that society develops and reproduces itself only via communicative action" (Habermas, "Actions, Speech Acts, Linguistically Mediated Interactions, and the Lifeworld (1988)", 248; emphasis T.S).

58 Honneth, The Critique of Power, 244, 293; cf. also Habermas' claim that "modernity has to create its normativity out of itself' (Habermas, The Philosophical Discourse of Modernity, 7).

59 Habermas, "A Reply", 249.

60 TCA 2, 148f.

61 Habermas, “A Reply”, 258; TCA 2, 150.

62 "From the vantage point of communication theory [...] strategic interactions can occur only within the horizon of lifeworlds already constituted elsewhere." (Habermas, "Actions, Speech Acts, Linguistically Mediated Interactions, and the Lifeworld (1988)", 248; emphasis T.S.); TCA 2, 149; Honneth, The Critique of Power, 299.

63 Detel, "System und Lebenswelt bei Habermas", 195.

64 This resonates with some ideas Cooke presents in Re-Presenting the Good Society. Cooke stresses that not all cognitive transformations are governed by argumentation (111), and she introduces the idea of "generalizable interests" as not a metaphysical idea, but as a mere representation of moral validity (184) - however, my suggestion of grounding normative validity in a social ontology adds to this account an answer to the question how some representation can achieve the status of a norm suited for critical evaluation in a given social context.

65 McCarthy, "Complexity and Democracy, or the Seducements of Systems Theory".

66 TCA 2, 154.

67 Habermas, "Actions, Speech Acts, Linguistically Mediated Interactions, and the Lifeworld (1988)", 249; Honneth, The Critique of Power, 297.

68 That is, normative conflicts which involve the norms which Habermas' critical theory intends to employ. cf. Honneth, The Critique of Power, $254 \mathrm{ff}$.

69 TCA 2, 333, 345.

70 Honneth, "The Social Dynamics of Disrespect", 75ff.

71 Weiss, "Verständigungsorientierung und Kritik", 118; Detel, "System und Lebenswelt bei Habermas", 189.

72 McCarthy, "Complexity and Democracy, or the Seducements of Systems Theory", 129ff., Honneth, The Critique of Power, 255. 
73 Mattias Iser, Empörung und Fortschritt (Frankfurt: Campus, 2008), 122.

74 Jürgen Habermas, Legitimation Crisis, tr. Thomas McCarthy (Heinemann: London, 1976).

75 Habermas, "Discourse Ethics", 65.

76 Jürgen Habermas, "Morality, Society, and Ethics. An Interview with Thorben Hviid Nielsen", Acta Sociologica 33(2), 1990, 94.

77 Jürgen Habermas "Reflections on Communicative Pathology (1974)", On The Pragmatics of Social Interaction, tr. Barbara Fultner (Cambridge, MA: MIT, 2001), 129-171.

78 TCA 1, 139, 332.

79 Maeve Cooke, Language and Reason. A Study of Habermas' Pragmatics (Cambridge, MA: MIT, 1994), 149; cf. for a proposal on how to integrate this critique: James Bohman, "Formal Pragmatics and Social Criticism", Philosophy \& Social Criticism, 11 (1986), 331-353; Habermas, "Morality, Society, and Ethics", 94.

80 TCA 2, 388; cf. also his claim that the "modern form of understanding is too transparent to provide a niche for this structural violence" (TCA 2, 196).

81 Habermas, “A Reply”, 226.

82 TCA 2, 116, 305, 322, 375.

83 TCA 2, 355, 324, 326, 364.

84 TCA 2, 373; Habermas, Legitimation Crisis, 48ff.; Benhabib, Critique, Norm, and Utopia, $231 \mathrm{ff}$.

85 Timo Jütten, “The Colonization Thesis: Habermas on Reification", International Journal of Philosophical Studies, 19(5), 2011, 706.

86 Cooke, Language and Reason, p. 111 (but compare also Cooke's suggestion on how to solve this problem in ch. 5)

87 Cf. Axel Honneth, Reification. A New Look at an Old Idea (Oxford: Oxford University Press, 2008), 55; Jütten, "The Colonization Thesis", 711; Cooke, Representing the Good Society, 53.

88 In this respect, I suggest a different methodological approach than that which is exemplified in Cooke, Representing the Good Society, ch. 6.

89 Of course this introduces a set of difficulties into the very concept of a "social ontology" that contemporary analytic accounts in this field do not envisage, especially with regard to the relationship between social ontology and rationality. This suggestion does not imply that these difficulties are already solved, but rather advocates a change in methodology. Specifically, I argue that we should approach the issue by questioning what constitutes the force of social critique, and by then working towards an evaluation of the rationality of critical claims, rather than starting the other way around, that is, with a strong notion of rationality that narrows our focus to include only the most rational forms of practices.

90 In this respect, there is an untapped potential for social theory in Robert Brandom's work, especially in the "normative pragmatics" he develops in his Making It Explicit. Reasoning, Representing, and Discursive Commitment (Cambridge, MA: Harvard University Press, 1994); Cf. also Titus Stahl, Eine kritische Theorie sozialer Praktiken, PhD Thesis (Frankfurt / Sydney: 2010).

91 Cf. Thomas McCarthy, "The Critique of Impure Reason: Foucault and the Frankfurt School”, Political Theory 18(3), 1990,456

92 Cf. the contributions in Heikki Ikäheimo and Arto Laitinen, eds. Recognition and Social Ontology (Leiden: Brill, 2011).

93 I am grateful to Axel Honneth, Maeve Cooke, Timo Jütten and Kristina Lepold for comments on earlier versions of this article. 